BELKIN, Alejandro (2018). Sindicalismo revolucionario y movimiento obrero en la Argentina. De la gestación en el Partido Socialista a la conquista de la FORA (1900-1915). Buenos Aires: Imago Mundi/Ediciones CEHTI, 320 páginas.

Lucas POY

Avances del Cesor, V. XV, № 19, diciembre 2018, pp. 181-183.

ISSNe 2422-6580 / ISSN 1514-3899 - http://web2.rosario-conicet.gov.ar/ojs/index.php/AvancesCesor/index

\title{
BELKIN, Alejandro (2018). Sindicalismo revolucionario y movimiento obrero en la Argentina. De la gestación en el Partido Socialista a la conquista de la FORA (1900-1915). Buenos Aires: Imago Mundi/Ediciones CEHTI, 320 páginas.
}

Lucas Poy Instituto de Historia Argentina y Americana "Dr. Emilio Ravignani" Universidad de Buenos Aires (UBA) Consejo Nacional de Investigaciones Científicas y Técnicas (CONICET)

Argentina

lucaspoy@gmail.com

Es indudable que la historia de los trabajadores y las izquierdas en Argentina es un campo que viene mostrando una significativa vitalidad por lo menos en la última década: así lo revela una profusión de investigaciones doctorales, eventos académicos, publicaciones periódicas e iniciativas institucionales. Los temas de interés son variados y heterogéneos, así como los períodos abordados: en cualquier caso, la producción historiográfica reciente sobre el período formativo del movimiento obrero y las corrientes políticas de izquierda -en los años finales del siglo XIX y las primeras décadas del siglo XX- ha sido abundante y variada, estimulando un campo de estudios que había tenido otro importante desarrollo en la déca- da de 1980, hace ya más de treinta años. En el terreno específico de los estudios sobre las fuerzas políticas activas en la clase trabajadora de ese período, no obstante, es posible advertir un desequilibrio manifiesto en cuanto a las corrientes analizadas. Mientras que anarquistas y socialistas -y más tarde comunistas- han recibido una atención sostenida y creciente, que permitió enriquecer los conocimientos sobre los orígenes de la izquierda argentina, la corriente sindicalista revolucionaria fue objeto de una atención mucho más marginal. El reciente libro de Alejandro Belkin representa un aporte fundamental para comenzar a llenar ese vacío historiográfico y perfilar así un cuadro más completo del universo de fuerzas políticas que se disputaban la hegemonía de esa joven y combativa clase trabajadora.

Sindicalismo revolucionario y movimiento obrero en la Argentina, editado en forma conjunta por Imago Mundi y Ediciones CEHTI como parte de una colección que ya lleva nueve volúmenes, es producto de la tesis doctoral del autor, defendida en la Universidad de Buenos Aires 
en 2017, y concentra los resultados de una investigación de más de una década, que habían sido publicados previamente solo de manera parcial. Belkin parte de considerar que existe una "descompensación mayúscula entre la importancia que alcanzó la corriente sindicalista y los pocos estudios que tratan sobre esta tendencia” (p. 18) y su trabajo está orientado tanto a destacar el rol fundamental que jugó el sindicalismo revolucionario en la historia del movimiento obrero argentino como a ofrecer una reconstrucción minuciosa de su historia que permita revertir el desconocimiento que aún la rodea. Se apoya para hacerlo en una variedad de fuentes, sobre todo periódicos políticos y gremiales, pero también libros de actas de organizaciones obreras, prensa comercial y otras fuentes estatales. Estructurado en cinco capítulos que se suman a una extensa introducción, el libro se ordena de manera cronológica y realiza un recorrido por los posicionamientos, estrategias y debates internos que llevaron a la corriente sindicalista revolucionaria de ser una fracción al interior del Partido Socialista a convertirse en la fuerza hegemónica del movimiento obrero desde la dirección de la FORA.

La obra de Belkin sostiene una serie de hipótesis de importancia que delimitan su lugar en el campo historiográfico y estructuran todo el libro. Las dos primeras implican una discusión con la interpretación canónica hecha por el propio Partido Socialista acerca de la ruptura sindicalista revolucionaria, que insistía en mostrar que esta fracción había logrado avanzar gracias a una astuta infiltración de ideas importadas de líderes europeos como Sorel y Labriola y que luego había ganado posiciones en las organizaciones sindicales a través de maniobras de diverso tipo. Belkin argumenta, en contraste, que el sindicalismo revolucionario fue un "producto genuino" de tensiones inter- nas entre sectores moderados y radicalizados al interior del PS, que se agudizaron en el año 1904 ante los intentos integracionistas del régimen y luego estallaron en 1905-1906 en una coyuntura de agudización represiva. Según el autor, las ideas del sindicalismo revolucionario europeo actuaron como un "armazón" que proporcionó un "esqueleto teórico" a un "malestar endémico con la orientación reformista de la conducción" del partido. También sostiene que el avance de su influencia en las organizaciones gremiales no se debió a maniobras sino a su capacidad de "empalmar" con una "corriente obrerista inorgánica, independiente del socialismo y el anarquismo" que desconfiaba de la política y a la cual el sindicalismo revolucionario supo dar expresión (pp. 45-46).

Otro conjunto de hipótesis que recorren el libro se orientan a marcar una diferencia con la historiografía existente. Belkin argumenta que la influencia de los sindicalistas revolucionarios fue "notablemente subvalorada" y se esfuerza en mostrar el rol jugado por esta corriente en algunos episodios clave de la lucha de clases de las dos primeras décadas del siglo XX. Su planteo es que, al reconsiderar la influencia del sindicalismo revolucionario, "la relevancia de las otras fuerzas, anarquistas y socialistas, necesariamente tiene que reajustarse", lo cual implica "una reinterpretación global del período" (p. 47). Por otra parte, Belkin también discute con investigaciones previas -entre ellas, los trabajos clásicos de David Rock- que centraron el análisis del sindicalismo revolucionario en su influencia sobre los gremios marítimos y ferroviarios: en el libro, el autor muestra que el rol protagónico de estos gremios fue un fenómeno tardío, recién a mediados de la década de 1910, y que en la decisiva etapa previa la hegemonía de los sindicalistas se desplegó desde otros gremios, menos estudiados, como 
los trabajadores de la madera (ebanistas) y los picapedreros.

Por otra parte, Belkin también desbroza un terreno mayormente inexplorado al examinar el período que se extiende desde 1910 hasta 1915, es decir entre la derrota de la huelga del Centenario y el noveno congreso de la FORA, una etapa que considera decisiva para comprender el avance de la influencia sindicalista y que efectivamente ha sido extremadamente descuidada por la historiografía existente. El autor sostiene además que resultó clave la alianza de los sindicalistas con aquel sector del anarquismo -también escasamente estudiadoque era contrario al principismo de la FORA del $\mathrm{V}$ Congreso y se mostraba partidario de la unidad sindical y de un entendimiento con la corriente sindicalista revolucionaria. Este enfoque relacional, que se esfuerza por comprender las particularidades de una corriente política ubicándola en el contexto más amplio de la arena de disputas que comparte con otras tendencias, resulta un aporte significativo de la historiografía reciente de las izquierdas, de la cual Belkin se nutre y a la cual contribuye.

Gracias a su seguimiento exhaustivo de las fuentes producidas por la corriente sindicalista revolucionaria y por sus adversarios, Belkin realiza un aporte significativo al conocimiento sobre el movimiento obrero argentino en las primeras dos décadas del siglo XX. Es eminentemente un trabajo de historia política -por momentos intelectual- antes que de historia social de la clase trabajadora: los avatares institucionales y las discusiones teóricas y programáticas reciben más atención que la composición social de los gremios analizados, los espacios que habitaban o las prácticas cotidianas que llevaban adelante en su militancia. Acaso por el mismo motivo, dialoga poco con la nutrida historiografía que puso de relieve los potenciales de un cruce entre estudios de género y análisis de la clase obrera. Dada la vacancia que mostraba el tema, de todos modos, esta minuciosa reconstrucción de la dinámica política e institucional resultaba indispensable para desbrozar el camino. Sindicalismo revolucionario y movimiento obrero en la Argentina se convertirá por ello en la obra de referencia sobre esta corriente política y constituye por lo tanto un libro de consulta necesaria para quienes se dedican a investigar sobre la historia temprana del movimiento obrero y la izquierda en Argentina. Aunque la reconstrucción extremadamente minuciosa de debates, reuniones y congresos puede hacer su lectura algo ardua, también resulta un trabajo accesible para un público más amplio, interesado por conocer las vicisitudes políticas que encontró el activismo sindical en las primeras dos décadas del siglo XX.
Recibido: 25-10-2018
Aceptado: 20-11-2018
Publicado: 07-12-2018 